\title{
Review of Aubrey Beardsley at Tate Britain
}

\author{
Sasha Dovzhyk
}

Aubrey Beardsley (1872-1898) entered the last Victorian decade a precocious 18-year-old with a passion for music, art, literature, and theatre, obliged to earn a living as a clerk at an insurance firm (Fig. 1). He died of tuberculosis two years before the decade's end, having lent his name to the period, an author of a thousand radical designs which achieved, in his own words, 'publicity without a frame, and beauty without modelling'. ${ }^{1}$ His art training encompassed evening classes attended irregularly over eighteen months. His art's effect traversed geographical and chronological boundaries alike. Beardsley's sharp, elegant, and easily reproducible drawings were circulated far and wide and absorbed by followers from Germany to China. The Beardsley Craze, as his heyday in the 1890 s was dubbed, is not yet over: in the spring of 2020 (4 March-25 May), Tate Britain has dedicated a major exhibition to his art.

Recognition by such an established institution would have flattered such a precarious artist. As Robert Ross recalls, Beardsley defended the Royal Academy, for instance, 'saying he would rather be an Academician than an artist, "as it takes only one man to make an artist, but forty to make an Academician". ${ }^{2}$ Tate Britain's exhibition secures Beardsley's place in the art canon, next to William Blake and Vincent Van Gogh, whose one-man displays occupied the very same space a few months prior. Like Blake's and Van Gogh's, Beardsley's show extends over a dozen softly lit rooms, a proof that his small-sized, mostly black-and-white designs may now populate grand spaces, unreachable to the graphic artist - financially insecure, critically ill, and incurably mischievous - during his lifetime.

Advertised as the largest show of Beardsley's work in fifty years, it assembles around two hundred pieces, including original drawings that are normally dispersed among British, American, and European collections. The exhibition opens with a room centred on the artist's early mythological

\footnotetext{
${ }^{1}$ Max Beerbohm's confession that, in 1896, he already felt 'a trifle outmoded' because he belonged 'to the Beardsley period' made Beardsley an emblem of the 189os; see The Works of Max Beerbohm (London: John Lane, The Bodley Head; New York: Charles Scribner's Sons, 1896), p. 16o; Aubrey Beardsley, 'The Art of the Hoarding', New Review, July 1894, pp. 47-55 (p. 54).

${ }^{2}$ Robert Ross, Aubrey Beardsley (London: John Lane, The Bodley Head, 19o9), p. 17.
} 


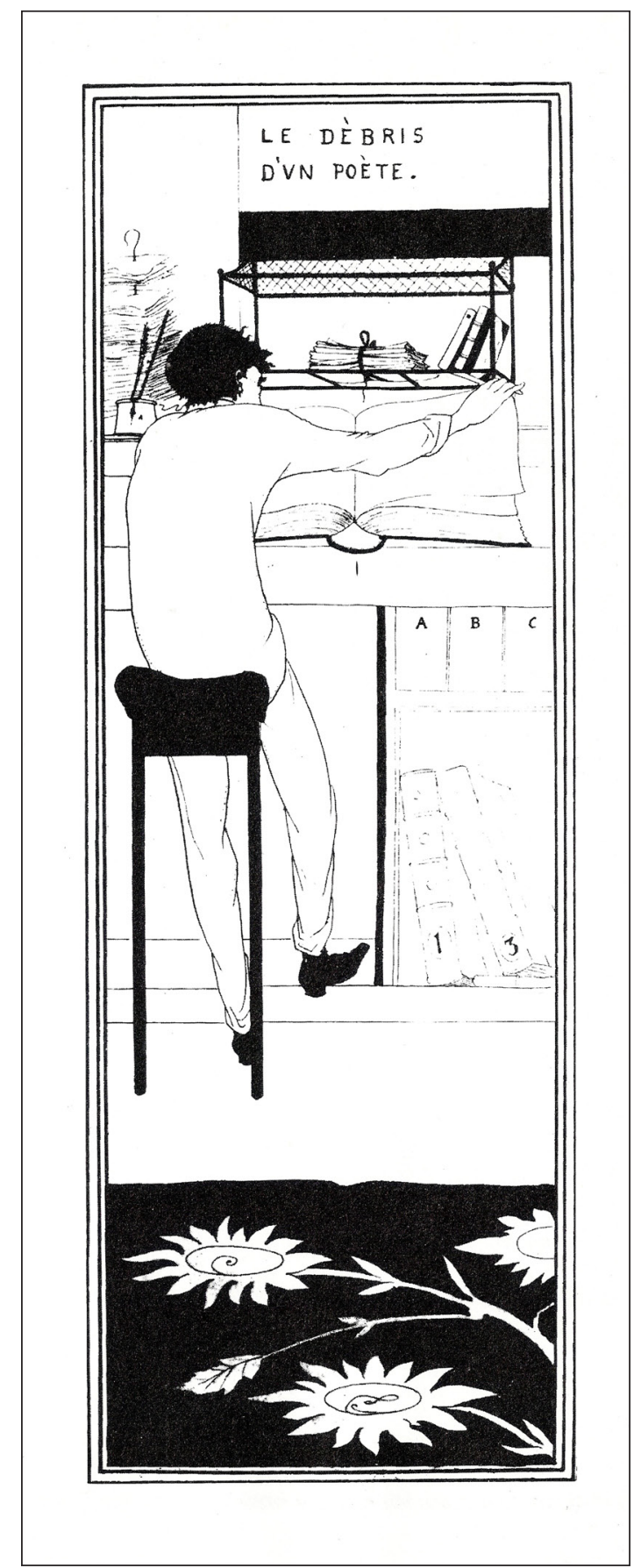

Fig. 1: Aubrey Beardsley, Le Dèbris [sic] d'un Poète, 1892, Indian ink and wash on off-white wove paper, Victoria and Albert Museum, London. Wikimedia Commons. 
images and Burne-Jonesean leanings, and proceeds to the first major design commission which resulted in iconoclastic illustrations for Malory's Morte Darthur (1893-94) as well as in Beardsley quitting his day job to pursue a career in art. The viewers are then exposed to his appropriation of a new stylized method, 'fantastic in conception but perfectly severe in execution' and 'suggestive of Japan', which evolved through the designs for Bon Mots of Smith and Sheridan (1893), Oscar Wilde's Salome (1894), and the Yellow Book (1894-95). ${ }^{3}$ During this period, the artist 'became a sort of household word and his fame, or notoriety as his enemies called it, was established' (Ross, p. 18). Pausing on Beardsley's striking posters and portraits of his social circle, the show then invites the viewers to contemplate the artist's quick changes of technique, from the deftness of neo-rococo 'embroideries' for the Savoy and The Rape of the Lock (1896) to the laconic style and erotic excess of illustrations for Aristophanes and Juvenal (1896). The display closes with a neat gallery devoted to Beardsley's influence on arts and culture which features drawings by 'Alastair', album covers of the Beatles, and Portrait of Marie Derval (1901) by Picasso, among other miscellaneous traces of twentieth-century Beardsleyana.

Tate Britain adopts its trademark approach of relaying, in a chronological manner through an orderly succession of rooms, the story of the man and his work. With knowledge, affection, and solemnity, it chaperones the viewers through the oeuvre of the artist who liked nothing more than 'to give Solemnity a shock'. ${ }^{4}$ And while doing so, the exhibition 'kills the thing [it] loves'.5

Beardsley is nothing if not theatrical, irreverent, and self-mocking. He reworked Richard Wagner's quasi-religious opera Tannhäuser (1845) into an ostentatious catalogue of sexual revelries (Under the Hill, 1896) and depicted the princess of Judaea as a courtesan in a Victorian straw bonnet, caught in the act of self-indulgence (The Black Cape, 1893) (Fig. 2). Characters of undefined gender filled his designs. His women were too bold, men too effeminate. His near-abstract compositions denied the laws of nature, and his every stroke bristled with the energy of youth cut short. The chronological arrangement of his drawings on the wall cannot convey the daring of the marvellous boy who made his figures levitate in the empty space of printed pages, anticipating the experiments of surrealism and non-figurative art. ${ }^{6}$

3 The Letters of Aubrey Beardsley, ed. by Henry Maas, J. L. Duncan, and W. G. Good (London: Cassell, 1970), pp. 34, 43.

4 Henry Harland, 'Aubrey Beardsley', Academy, 10 December 1898, pp. 437-38 (p. $\left.43^{8}\right)$.

5 Oscar Wilde, The Ballad of Reading Gaol (London: Smithers, 1898), p. 2.

${ }^{6}$ For the initial curtailed publication of Beardsley's erotic novella, see Aubrey Beardsley, 'Under the Hill', Savoy, January 1896, pp. 151-70, and April 1896, pp. 187-96. For the version close to the original manuscript, see Aubrey Beardsley, The Story of Venus and Tannhäuser (London: [Smithers], 1907). 


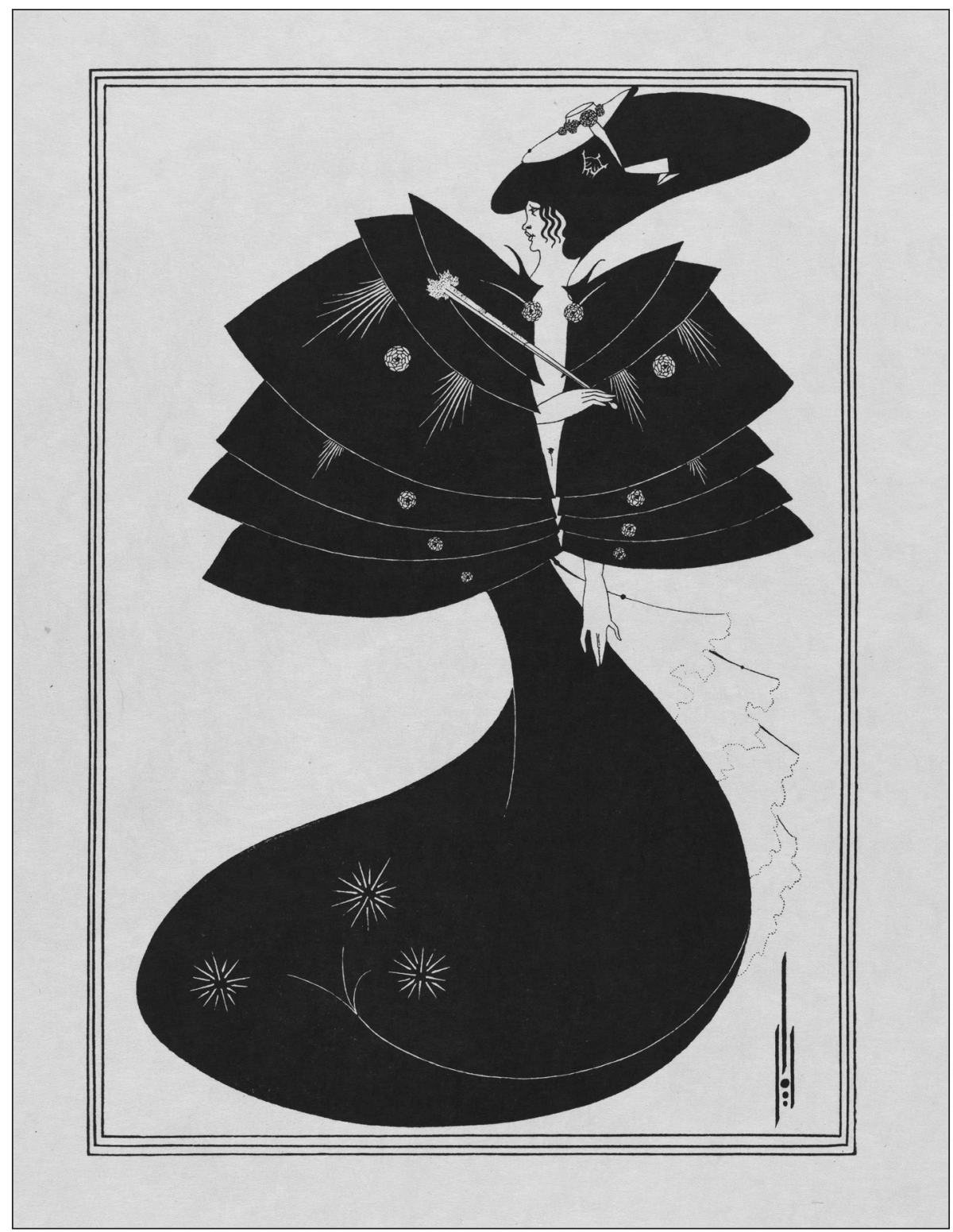

Fig. 2: Aubrey Beardsley, The Black Cape, 1893, Indian ink on white wove paper, Princeton University Library, Princeton, NJ, Aubrey Beardsley Collection (RS227). Wikimedia Commons.

Tate Britain fails to mediate the Beardsleyesque because it does not take 'full advantage of [an exhibition's] inherently spatial-temporal medium' - the aspect which, as Madeleine Kennedy notes, defines 'the most interesting and progressive exhibitions'. Unlike those shows which 
'seek to activate no other sensory faculties than merely looking at a procession of isolated images, "exhibitions that made art history" tend to be characterized by highly spatial, involved and affective experience'.7 Tate Britain's Aubrey Beardsley offers an art historical treatise rather than an aesthetic experience. It misses the opportunity to immerse new audiences in the artist's wickedly camp sensibility, eroticized object world, and dramatic contrasts of light and darkness (Fig. 3).

Thinking of exhibitions that, in Kennedy's words, 'embrace the spatial-temporal nature of their medium', one can recall stylized tributes to Tim Walker ('Wonderful Things', 2019-20), Frida Kahlo ('Making Herself Up', 2018), or Alexander McQueen ('Savage Beauty', 2015) recently staged at the V\&A. The museum's legendary exhibition of Beardsley's work, curated by Brian Reade in 1966, revived the Beardsley Craze for the latter part of the twentieth century. ${ }^{8}$ It is tempting to speculate that the V\&A would have been well suited to introduce Beardsley to the twenty-first century audiences in a similarly effective way.

As the curator of the Serpentine Galleries Hans Ulrich Obrist observes, contemporary exhibitions have turned into 'a mass medium and a ritual. The curator sets it up so that it becomes an extraordinary experience and not just illustrations or spatialised books.'9 Employing the mode of representation which can be categorized as a 'spatialised book', Tate Britain's show embarks upon a task which has already been accomplished. Indeed, the exhibition takes place after the landmark publication of Linda Gertner Zatlin's Aubrey Beardsley: A Catalogue Raisonné in 2016. This extraordinary two-volume work brought together nearly 1100 drawings, supplied with specialist art historical commentary, bibliographical, and provenance information. More than an indispensable guide for scholars, the catalogue raisonné is a beautifully designed object which utilizes Beardsley's medium of choice, the art of black and white. Turning its glossy pages, the reader catches the carousel of evolving styles, absorbs Beardsley's inexhaustible invention, and confronts the sheer immensity of his corpus. Perhaps it is the printed page after all that best conveys the effect and affect of Beardsley's art.

7 Madeleine Kennedy, 'Documenting the Marvelous: The Risks and Rewards of Relying on Installation Photographs in the Writing of Exhibition History', Stedelijk Studies, 2 (2015) <https://stedelijkstudies.com/journal/documenting-the-marvelous-the-risks-and-rewards-of-relying-on-installation-photographs-in-the-writingof-exhibition-history/> [accessed 5 April 2020].

8 See the catalogue, Brian Reade, Aubrey Beardsley (London: Her Majesty's Stationery Office, 1966).

9 Stuart Jeffries and Nancy Groves, 'Hans Ulrich Obrist: The Art of Curation', Guardian, 23 March 2014, Art and Design section <https://www.theguardian.com/ artanddesign/2014/mar/23/hans-ulrich-obrist-art-curator $>$ [accessed 5 April 2020]. 




Fig. 3: Aubrey Beardsley, The Masque of the Red Death, 1894, Indian ink on white paper, repr. in Illustrations to Edgar Allen Poe (Indianapolis: Aubrey Beardsley Club, 1926). The British Library Board, Wikimedia Commons. 
The printed medium is also a promise of persistence. Because of the coronavirus outbreak, the Aubrey Beardsley show was allowed to run less than a fortnight, mirroring the curtailed career of the artist who died, as Wilde so poetically puts it, 'at the age of a flower', but whose afterlives are still burgeoning worldwide. ${ }^{10}$

10 The Letters of Oscar Wilde, ed. by Rupert Hart-Davis (New York: Harcourt, Brace and World, 1962), p. 719 . 